JURNAL PANGAN DAN GIZI Vol (No): 24-33, April 2020

ISSN (Online) : 2656-0291

Tersedia online di http://jurnal.unimus.ac.id/index.php/JPDG

\title{
PENGARUH PENAMBAHAN TEPUNG PISANG KEPOK PUTIH TERHADAP SIFAT FISIK DAN SENSORI STIK
}

\section{THE EFFECT OF ADDITION OF WHITE KEPOK BANANA FLOUR TO PHYSICAL CHARACTERISTIC AND SENSORY OF STIK}

\author{
Muthia Damayanti, Wikanastri Hersoelistyorini \\ Program Studi Teknologi Pangan \\ Universitas Muhammadiyah Semarang \\ Email : muthiadamayanti.md@gmail.com
}

\begin{abstract}
Stick is type of pastry with a frying treatment with oil, usually made from wheat flour and tapioca. Banana flour is one of the flour products that can be used making sticks because they are easily mixed into various preparations and enriched with nutrients. The general objective of this study was to determine the effect of adding white kepok banana flour to physical properties (hardness) and sensory sticks. The research method of banana sticks consisted of 4 treatments of adding white kepok banana flour which were 0, 10, 20 and 30 grams. Each treatment was repeated 6 times, resulting in 24 experimental units. The results showed that there was a significant effect of adding white kepok banana flour to physical characteristics (hardness) and sensory sticks. The best physical and sensory properties were found in the manufacture of sticks with the addition of 10 grams of white kepok banana flour with the results of proximate analysis of water content of $9.74 \%$, ash content of $0.93 \%$, fat content of $35.86 \%$, protein $3.83 \%$ and carbohydrates $49,64 \%$. The more white kepok banana flour is added, the resulting stick will be harder and produce a more brownish color, caramel aroma and a slightly sweet taste.
\end{abstract}

Keyword: banana flour, banana stick, hardness 


\section{PENDAHULUAN}

Tepung pisang kepok merupakan salah satu bentuk alternatif produk setengah jadi yang disarankan karena, memiliki daya simpan yang sangat baik, mudah dicampurkan ke dalam berbagai olahan, diperkaya zat gizi, mudah dibentuk dan lebih cepat dimasak sesuai tuntutan kehidupan modern yang serba praktis (Winarno, 2000). Tepung pisang sangat cocok dikembangkan sebagai potensi pangan lokal karena memiliki kandungan zat gizi yang bermanfaat. Komposisi fisik dan kimia tepung pisang kepok yaitu kadar air 13,84\%, kadar abu 2,69\%, kadar lemak $0,52 \%$, serat kasar $1,40 \%$, protein $2,60 \%$ dan pati 59,62\% (Palupi, 2012). Tepung pisang dapat dijadikan berbagai macam olahan salah satunya stik. Stik adalah sejenis camilan yang memiliki tekstur renyah dan gurih. Stik umumnya dibuat dari campuran tepung terigu, tepung maizena, telur ayam, mentega, air es, minyak goreng, bawang putih, merica bubuk, dan garam (Pratiwi, 2013). Proses
Pembuatan stik diawali dengan mencampur seluruh bahan kering meliputi tepung terigu, tepung maizena, merica bubuk dan garam. Proses selanjutnya ditambahkan telur ayam yang telah dikocok dan bawang putih yang telah dihaluskan serta sedikit air es hingga didapat adonan kalis (Kumara, 2016). Adapun tujuan dari penelitian ini adalah mengetahui pengaruh penambahan tepung pisang kepok putih terhadap sifat fisik (kekerasan) dan sensori stik.

\section{Bahan dan Metode}

\section{Bahan}

Bahan utama yang digunakan dalam penelitian ini adalah tepung pisang kepok putih yang diperoleh dari penelitian sebelumnya dengan gram penambahan tepung pisang $0,10,20$ dan 30 gram. Bahan baku yang digunakan dalam pembuatan stik yaitu tepung terigu dengan bahan pendukung yaitu garam, merica bubuk, bawang putih, telur ayam, mentega dan minyak goreng. Berbagai bahan kimia untuk analisis proksimat. 
Metode

Penelitian ini melalui beberapa tahapan yaitu: 1) pembuatan stik dengan penambahan tepung pisang kepok putih Pratiwi, 2013), 2) pengujian kekerasan stik berbahan tepung pisang kepok putih, 3) pengujian mutu sensori uji hedonik 4) analisis proksimat stik berbahan tepung pisang kepok putih.

\section{Pembuatan Stik Berbahan Pisang} Kepok Putih ( Pratiwi, 2013)

Ditimbang campuran tepung terigu dengan tepung pisang. Ditambahkan tepung maizena $10 \mathrm{~g}$, garam $2 \mathrm{~g}$, merica bubuk $1 \mathrm{~g}$, putih dan kuning telur $10 \mathrm{~g}$, margarin $20 \mathrm{~g}$, dan air. Dicampur hingga kalis lalu dibulatkan dan diistirahatkan selama 15 menit. Adonan kemudian dipipihkan dengan penggiling mie dengan ketebalan 2-4 mm. Dipotong dengan panjang 5-8 cm. Digoreng selama 2-3 menit dengan temperatur $\pm 150{ }^{\circ} \mathrm{C}$. Setelah matang diangkat dan ditiriskan selama 5 menit. Kemudian dikemas.

\section{Analisis Kekerasan (Muina, 2013)}

Analisis kekerasan diperlukan untuk menentukan sifat fisik bahan yang berhubungan dengan daya tahan atau kekuatan suatu bahan terhadap tekanan. Analisis ini menggunakan alat yaitu texture analyzer. Texture analyzer adalah alat yang terkait dengan penilaian dari karakteristik mekanis suatu materi, di mana alat tersebut diperlakukan untuk menentukan kekuatan materi dalam bentuk kurva. 
Pengujian mutu sensori uji hedonik

(Rahayu, 2001)

Pengujian sensori tepung pisang kepok yaitu uji mutu hedonik yang meliputi : warna, tekstur, rasa dan aroma. Uji sensori menghasilkan skala hedonik yaitu:(1) Sangat Tidak Suka, (2) Tidak Suka, (3) Agak Suka, (4) Suka, (5) Sangat Suka.

Hasil uji skala hedonik diubah menjadi skala skoring dinilai dari sifat produk yang disajikan dengan menggunakan 20 orang panelis yang berasal dari mahasiswa jurusan Teknologi Pangan Universitas Muhammadiyah Semarang, yang tergolong panelis agak terlatih. Bahan uji organoleptik disajikan dalam bentuk bubuk tepung kemudian panelis diminta untuk mengisi penilaian sesuai dengan lembar yang dibuat oleh penyaji.

\section{HASIL DAN PEMBAHASAN}

\section{Kekerasan}

Analisis kekerasan diperlukan untuk menentukan sifat fisik bahan yang berhubungan dengan daya tahan atau kekuatan suatu bahan terhadap tekanan yaitu menggunakan Texture analyzer (Muina, 2013). Diagram rerata kekerasan stik dapat dilihat pada Gambar 1.

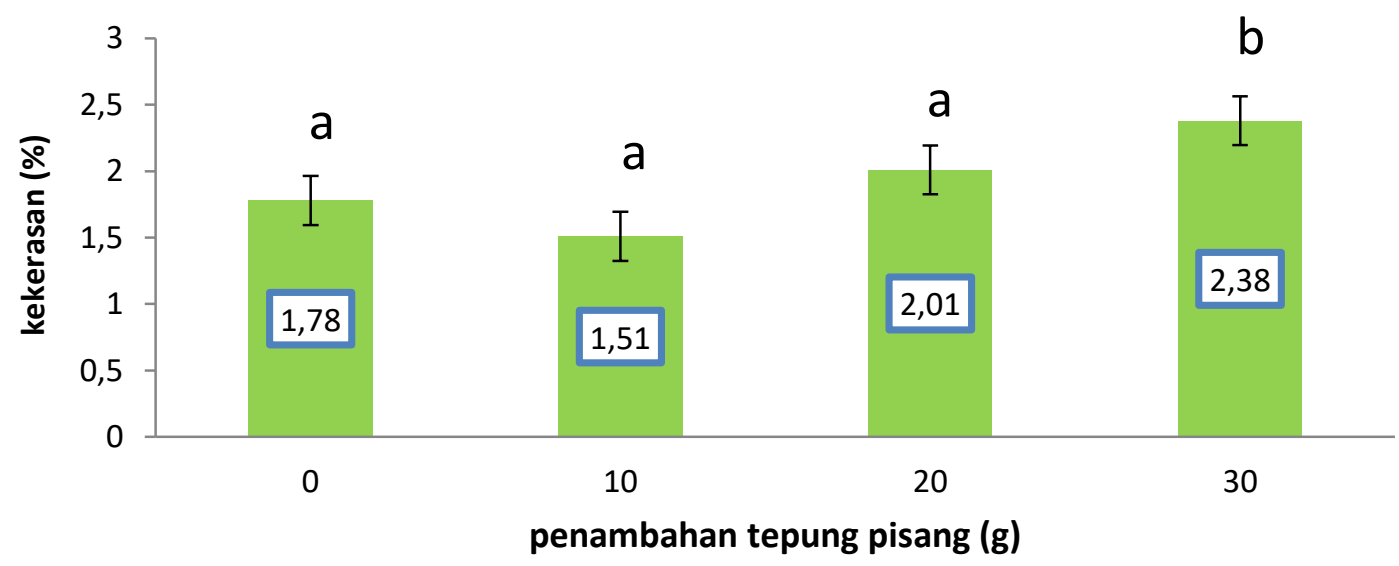


Gambar 1. Rerata kekerasan stik penambahan tepung pisang kepok putih Keterangan : Notasi huruf yang berbeda menunjukkan berbeda nyata.

Hasil penelitian tersebut tepung pisang kepok akan menghasilkan menunjukkan bahwa stik pisang kepok kerenyahan yang berbeda dari kue kering putih dengan penambahan 10 gram tepung biasanya, karena dipengaruhi oleh pisang kepok putih dengan nilai rerata 1,51 pemakaian tepung dan lemak yang akan merupakan stik pisang kepok putih dengan membuat tekstur kue kering lebih rapuh nilai kekerasan terbaik. Hasil penelitian dan renyah. Kekerasan pada produk kue tersebut sesuai dengan yang dilaporkan kering juga dapat dipengaruhi oleh protein, Kumara (2016) bahwa kerenyahan stik pembentuk gluten, kandungan lemak dan merupakan salah satu faktor penting granula pati. Pada tepung pisang tidak penentu hasil stik terbaik. Kerenyahan memiliki gluten sebanyak tepung terigu pada stik dipengaruhi oleh penggunaan sehingga berpengaruh terhadap kekerasan tepung terigu dan proses penggorengan. kue kering yang dihasilkan (Wijaya, 2017).

Sedangkan menurut Rangkuti (2015)

\section{Sensori Stik}

bahwa kue kering yang disubstitusi dengan

Aroma

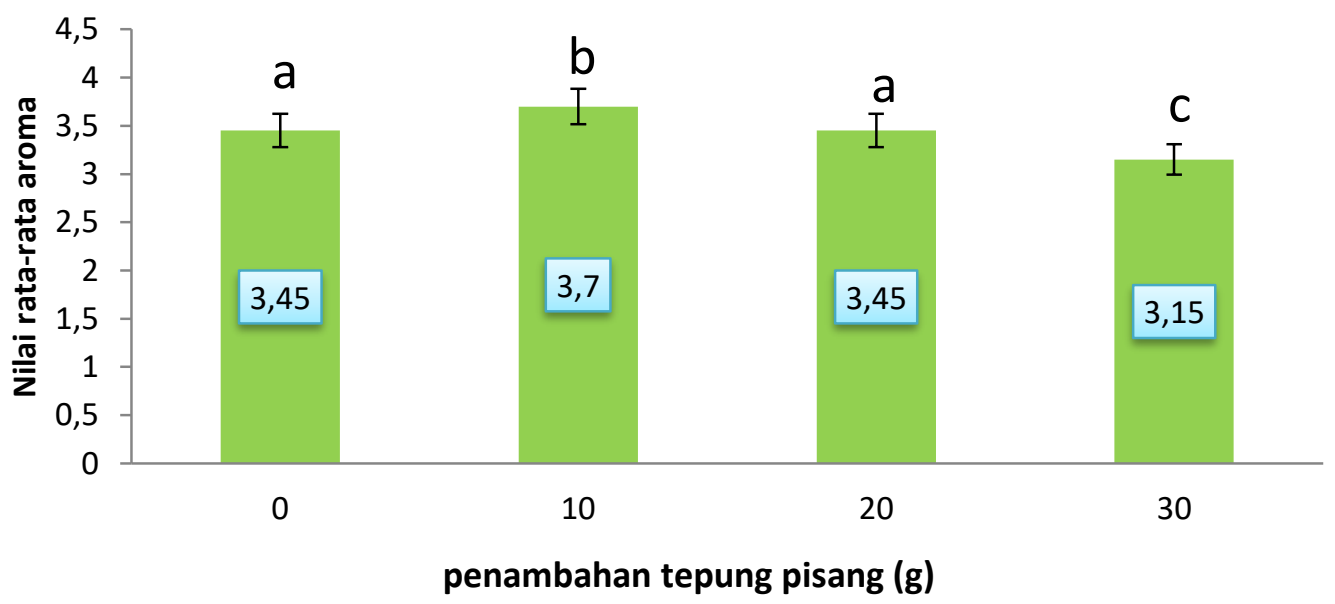

Gambar 2. Rerata sensori aroma stik penambahan tepung pisang kepok putih Keterangan : Notasi huruf yang berbeda menunjukkan berbeda nyata. 
Hasil analisis penambahan tepung pisang 10 gram merupakan stik pisang kepok putih dengan nilai sensori aroma terbaik secara statistik. Hal tersebut disebabkan karena pada perlakuan penambahan tepung pisang 0 gram aroma yang dihasilkan adalah aroma khas tepung terigu saja. Sedangkan pada penambahan tepung pisang 10, 20, dan 30 aroma yang dihasilkan adalah aroma gurih manis. Namun semakin banyak penambahan tepung pisang menyebabkan aroma manis sedikit berbau gosong dikarenakan gula

pada tepung pisang dan proses penggorengan yang kurang dikontrol. Sesuai dengan yang dilaporkan oleh Yasinta (2017) bahwa semakin banyak penambahan tepung pisang menyebabkan aroma karamel yang akan semakin terasa pada produk kue kering. Sedangkan menurut Antarsina et al., (2004) pisang memiliki senyawa volatil yakni isoamileter yang akan mempengaruhi aroma dari kue kering yang terbuat dari tepung pisang.

\section{Warna}

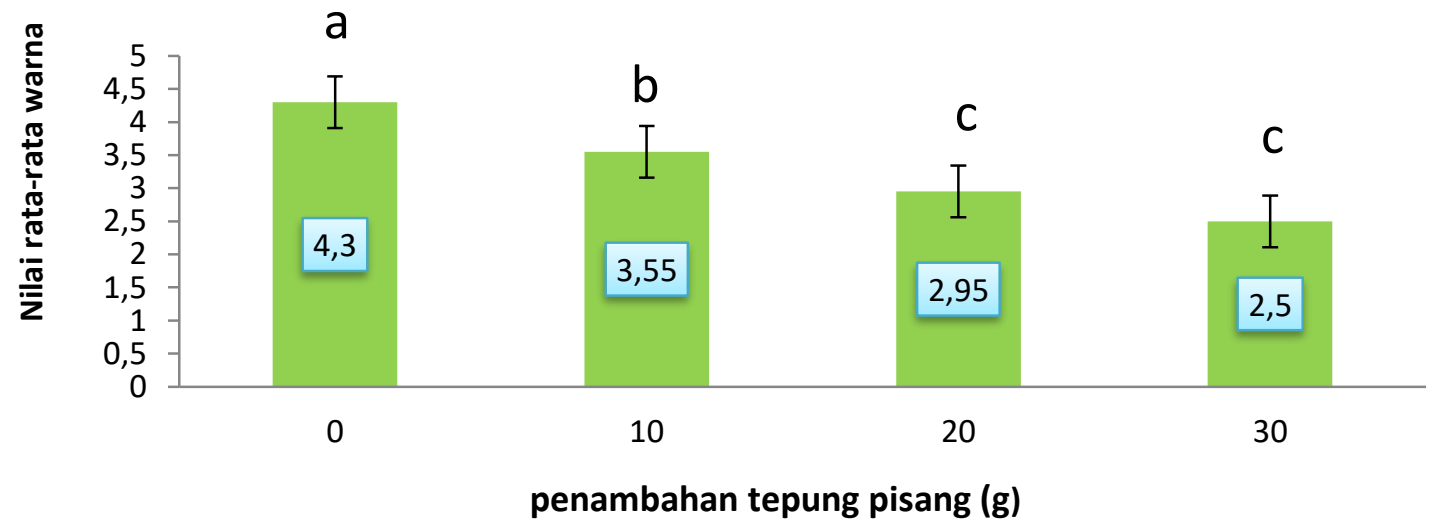

Gambar 3. Rerata sensori warna stik penambahan tepung pisang kepok putih Keterangan : Notasi huruf yang berbeda menunjukkan berbeda nyata.

Hasil uji sensori warna stik pisang kandungan gula dan komponen protein diperoleh kesukaan panelis tertinggi yaitu tepung dalam pisang kepok putih pada stik tanpa penambahan tepung pisang. terdegradasi saat penggorengan, yang Hal ini disebabkan karena adanya menyebabkan sedikit kecoklatan pada 
perlakuan penambahan tepung pisang panelis terhadap warna stik yang paling kepok putih 10, 20, dan 30 gram (Wijaya, tinggi yaitu pada penambahan 0 gram 2017). Sesuai dengan yang dilaporkan oleh tepung pisang.

Anggraini (2016) bahwa daya terima

\section{Rasa}

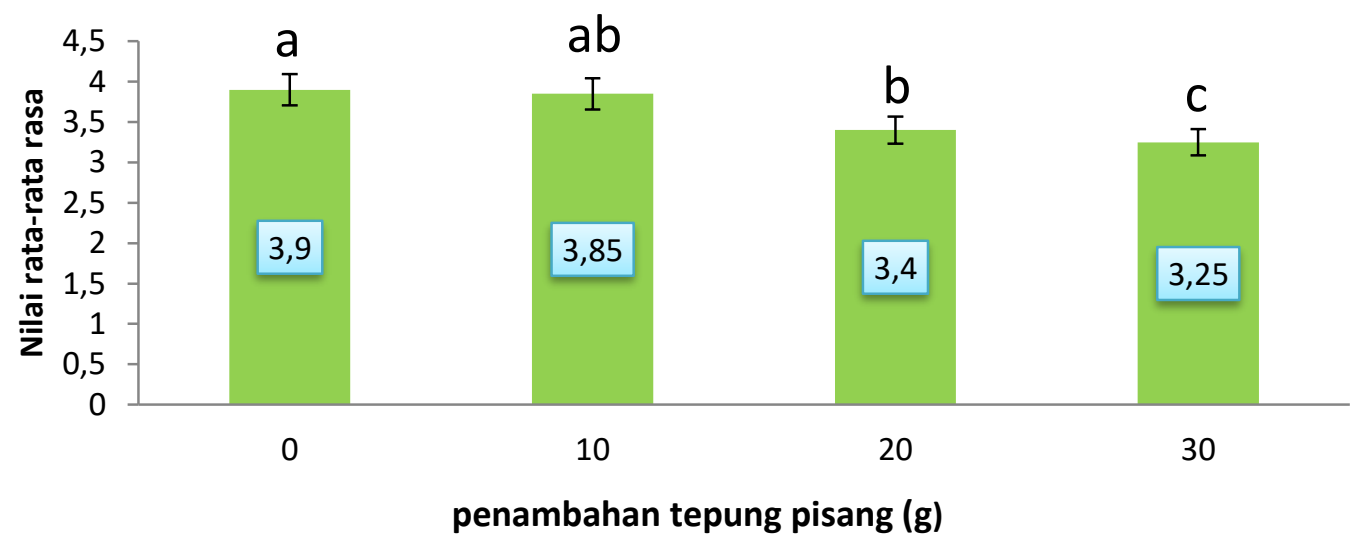

Gambar 4. Rerata sensori rasa stik penambahan tepung pisang kepok putih Keterangan : Notasi huruf yang berbeda menunjukkan berbeda nyata.

Hasil pengujian tersebut dengan pendapat Fernanda et al., (2017) menunjukkan bahwa penambahan tepung bahwa banyaknya tepung pisang yang pisang 0 gram merupakan stik pisang digunakan akan mendominasi dan kepok putih dengan nilai sensori rasa menutupi tepung terigu. Sehingga rasa terbaik dengan nilai rerata 3,9 dan gurih pada stik seiring bertambahnya menghasilkan rasa yang gurih. Sesuai tepung pisang akan memudar.

\section{Tekstur}




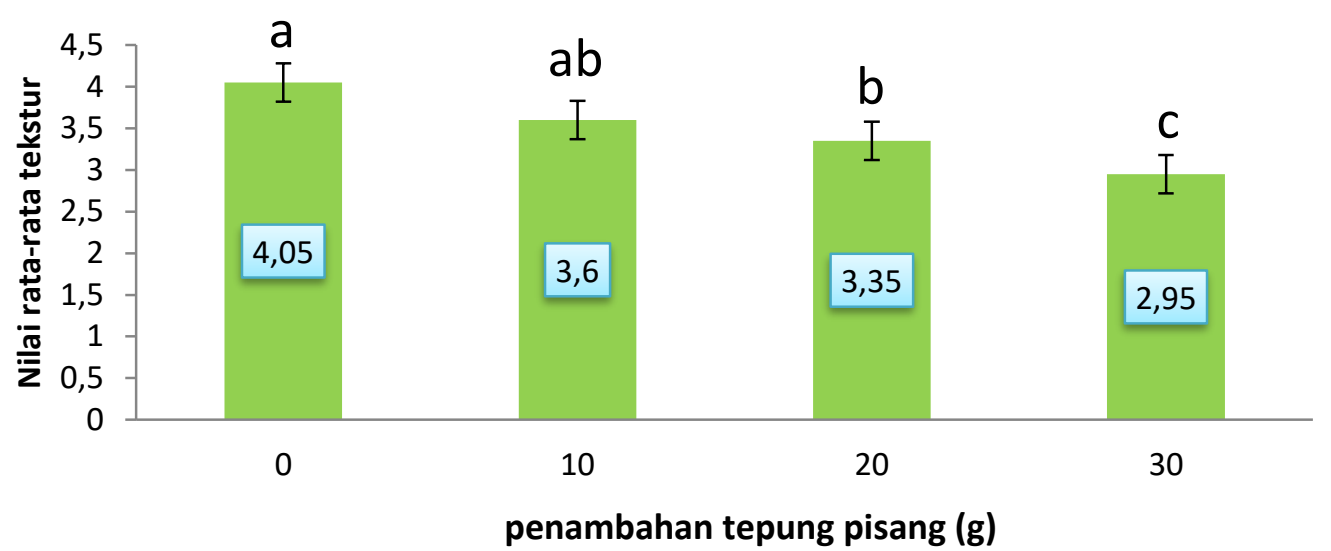

Gambar 5. Rerata sensori tekstur stik penambahan tepung pisang kepok putih Keterangan : Notasi huruf yang berbeda menunjukkan berbeda nyata.

Hasil analisis menunjukkan hasil tertinggi diperoleh oleh stik tanpa penambahan tepung pisang kepok putih $(0$ gram). Hal ini berbeda dengan hasil pengujian tekstur kue kering dari tepung pisang yang dilaporkan oleh Silfia (2012) bahwa tekstur kue kering semakin renyah dan disukai oleh panelis seiring bertambahnya konsentrasi penambahan tepung pisang disebabkan oleh kandungan pati pada pisang yang semakin tinggi maka akan meningkatkan tingkat kerenyahan produk. Begitu pula yang dilaporkan oleh Yasinta (2017) bahwa penambahan tepung pisang meningkatkan kerenyahan produk kue kering, dikaitkan dengan kandungan air pada tepung terigu lebih tinggi dibandingkan tepung pisang. Karena kemudahan patah sangat dipengaruhi oleh kandungan air pada bahan yang semakin sedikit menjadikan tekstur menjadi semakin kering sehingga akan mengakibatkan produk yang lebih mudah patah. Penurunan tingkat kesukaan terhadap tekstur stik pisang diakibatkan karena faktor penyimpanan stik yang tidak dikontrol dan dikemas menggunakan kemasan plastik klip, sehingga ujung stik yang bersiku menyebabkan lubang-lubang kecil pada plastik kemasan yang memungkinkan udara masuk dan menyebabkan kandungan air pada stik bertambah. 
Penurunan tingkat kesukaan

terhadap tekstur stik pisang diakibatkan

karena faktor penyimpanan stik yang tidak

dikontrol dan dikemas menggunakan

kemasan plastik klip, sehingga ujung stik

yang bersiku menyebabkan lubang-lubang

kecil pada plastik kemasan yang

memungkinkan udara masuk dan

menyebabkan kandungan air pada stik

bertambah.

Proksimat
Setiap variabel dari sifat fisik dan organoleptik stik pisang kepok putih didapatkan stik pisang dengan formulasi terbaik setelah dianalisis secara statistik. Stik dengan penambahan 10 gram tepung pisang kepok merupakan produk stik terbaik dinilai dari hasil pengujian sifat fisik dan sensori stik pisang kepok putih dalam penelitian ini. Hasil analisis stik pisang dengan formulasi terbaik disajikan pada Tabel 1.

Tabel 1. Komposisi kimia stik pisang kepok putih

\begin{tabular}{lc}
\hline Komposisi Kimia & Hasil (\%) \\
\hline Kadar Lemak & 35,86 \\
Kadar air & 9,74 \\
Kadar abu & 0,93 \\
Protein & 3,83 \\
Karbohidrat & 49,64
\end{tabular}

Hasil analisis kimia stik pisang namun berbeda dengan hasil analisis kepok putih diperoleh kadar lemak stik penelitian Kumara (2016) yaitu hasil pisang kepok putih dengan penambahan 10 analisis kadar lemak stik 20,70 persen. gram pisang kepok puth yaitu 35,86 Sedangkan hasil analisis kadar air stik persen, hasil tersebut sesuai dengan syarat pisang kepok putih dengan penambahan 10 mutu makanan ringan ekstrudat yang sudah gram tepung pisang kepok putih yaitu 9,74 ditetapkan SNI (2000) yaitu syarat persen terhitung belum sesuai dengan maksimal kadar lemak makanan ekstrudat syarat mutu kadar air makanan ringan dengan penggorengan sebesar 38,00 persen ekstrudat yaitu maksimal 4. Hal ini 
dimungkinkan karena penambahan tepung pisang yang berbeda.

\section{KESIMPULAN}

Berdasarkan penelitian yang dilakukan dapat disimpulkan bahwa penambahan tepung pisang kepok putih pengaruh nyata terhadap karakteristik fisik (kekerasan) dan sensori. Hasil analisis sensori stik pisang dengan penambahan tepung pisang kepok putih ada pengaruh terhadap warna, aroma, rasa dan tekstur. Semakin bertambahnya

\section{DAFTAR PUSTAKA}

[AOAC] Association of Official Analitycal Chemist. 2005. Official Method of Analysis of The Association of Official Analytical of Chemist. Arlington, Virginia, USA: Association of Official Analytical Chemist, Inc.

Anggraini ,S. 2016. Pengaruh Substitusi Tepung Pisang Kepok Putih pada Eggroll terhadap Kadar Vitamin $C$ dan Daya Terima. (Skripsi). Fakultas Ilmu Kesehatan. Universias Muhammadiyah Surakarta.

Antarsina, S. S., Rina, Y., Umar, S., Rukayah. 2004. Pengolahan buah pisang dalam mendukung pengembangan agroindustri di Kalimantan (dalam Prosiding Seminar Nasional Klinik Teknologi Pertanian sebagai Basis Pertumbuhan Usaha Agribisnis menuju Nelayan mandiri), Puslitbang Sosek Pertanian: 724-746.

Fernanda, A.G., Widani,Y.A., Kurniawati, L. 2017. Karakteristoik Stik Vegetarian tepung pisang kepok putih yang ditambahkan maka akan menghasilkan stik pisang dengan warna yang semakin kecoklatan, aroma karamel, rasa sedikit manis dan tekstur yang keras. Sifat fisik dan sensori terbaik terdapat pada stik penambahan tepung pisang 10 gram dengan nilai proksimat stik : kadar air 9,74\%, kadar abu 0,93\%, kadar lemak $35,86 \%$, protein $3,83 \%$ dan karbohidrat $49,64 \%$.

dengan Substitusi Tepung Pisang Tanduk (Musa paradisiaca formatypica) dan Tempe sebagai Sumber Protein. Jurnal JITIPARI, (4) :75-81.

Kumara, S.W. 2016. Pengembangan Stik Bawang Substitusi Kulit Pisang Kepok (Musa paradisiaca) Disuplementasi Torbagun (Coleus amboinicus L.) Bagi Wanita sindrom Pramenstruasi. (Skripsi). Fakultas Ekologi Manusia, Institut Pertanian Bogor.

Muina, A. 2013. Tekstur Analizer. https://anitamuina.wordpress.com. (22 Desember 2017).

Palupi, H.T. 2012. Pengaruh Jenis Pisang dan Bahan Perendam terhadap Karakteristik Tepung Pisang (Musa Spp.). Jurnal Teknologi Pangan,(4) 1: 102-120.

Pratiwi, F. 2013. Pemanfaatan Tepung Daging Ikan Layang utuk Pembuatan Stik Ikan. Fakultas Teknik, Universitas Negeri Semarang. 
Rahayu. 2001. Penuntun Praktikum Penilaian Organoleptik. Fakultas Teknologi Pertanian, Institut Pertanian Bogor.

Rangkuti, N. 2015. Pengaruh Substitusi Tepung Pisang Kepok terhadap Kualitas Cookies. (Skripsi). Fakultas Teknik. Universitas Negeri Padang.

Silfia, S. 2012. Pengaruh Subsiusi Tepung Pisang terhadap Mutu Kue Kering. Jurnal Litbang Industri, (2) 1:43-49.

SNI-01-2886-2000. Syarat Mutu Produk Makanan Ringan Ekstrudat. Deperindag. Jakarta.

Wijaya ,V.A. 2017. Pengaruh Jenis Larutan Perendam terhadap Kualitas
Tepung Pisang Kepok ( Musa paradisiaca) yang Diaplikasikan pada Produk Cookies. (Skripsi), Fakultas Teknologi Pertanian. Universitas Katolik Soegijapranata Semarang.

Winarno,F.G . 2000. Potensi dan Peran Tepung-tepungan bagi Industri Pangan dan Program Perbaikan Gizi Makanan. (Semhas). Interaktif Penganekaragaman Makanan untuk Memantapkan Ketersediaan Pangan. PT. Gramedia Pustaka Utama. Jakarta.

Yasinta, U.N.A. 2017. Pengaruh Substitusi Tepung Terigu dengan Tepung Pisang terhadap Sifat Fisikokimia dan Organoleptik Cookies. Jurnal Aplikasi Teknologi Pangan, (6) 3:119-123. 